\title{
Avicides $^{1}$
}

\section{Frederick M. Fishel ${ }^{2}$}

\section{Background}

By and large, birds are beneficial because they provide enjoyment and recreation to humans and are vital for ecosystem balance. However, occasionally some species can compete with human interests. When these situations occur, some forms of control may become necessary. Besides exclusion, trapping, and sanitation, pesticide use is one option in a pest-management professional's toolbox that may be selected when an applicable situation calls for it. Avicides are pesticides designed to kill or repel pest birds. Prior to selecting avicide use, pest-management professionals must bear in mind that migratory birds are legally protected species under the Migratory Bird Treaty Act. Violation of this law can result in severe penalties. This document, written for pest-management professionals and growers, addresses avicides currently registered for use in Florida.

Why are birds occasionally pests? These creatures can be pests on their own or in small groups, but most commonly in large flocks. There are five primary concerns with pest birds:

1. Destruction of agricultural commodities;

2. Contamination of foodstuffs or defacing of structures with their feces;
3. Transmission of diseases, directly and indirectly, to people, poultry, and other livestock;

4. Hazards at airports and roadways; and

5. Being a nuisance by affecting our comfort, aesthetics, or sporting values.

\section{Do certain species of birds tend to be pests more often} than others? Yes; several species, including crows (Corvus brachyrhynchos), starlings (Sturnus vulgaris), blackbirds (Agelaius phoeniceus), and pigeons (Columba livia), are considered the most notorious. For example, crows can be annoying because of their high-pitched calls and propensity for getting into trashcans. But some birds are more than annoying and are dangerous for human health. Histoplasmosis, a fungal disease affecting the human respiratory tract, is associated with droppings from blackbirds and starlings. Cryptococcosis, another fungal disease similar to histoplasmosis in its effects on humans, is carried by pigeons.

\section{When is avicide use justified in the control of pest}

birds? Integrated pest management (IPM) is an ecological approach to pest control. It is based on the habitat and life cycle of the pest. IPM combines all appropriate pest control strategies. These strategies may include both chemical and nonchemical methods. The goal of an IPM program is to reduce pest populations to an acceptable level in a way that

1. This document is PI281, one of a series of the Agronomy Department, UF/IFAS Extension. Original publication date September 2019. Visit the EDIS website at https://edis.ifas.ufl.edu for the currently supported version of this publication.

2. Frederick M. Fishel, professor, Agronomy Department, and director, Pesticide Information Office, UF/IFAS Extension, Gainesville, FL 32611.

The use of trade names in this publication is solely for the purpose of providing specific information. UF/IFAS does not guarantee or warranty the products named, and references to them in this publication do not signify our approval to the exclusion of other products of suitable composition. Use avicides safely. Read and follow directions on the manufacturer's label.

The Institute of Food and Agricultural Sciences (IFAS) is an Equal Opportunity Institution authorized to provide research, educational information and other services

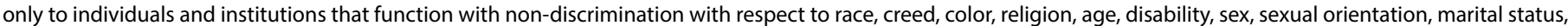

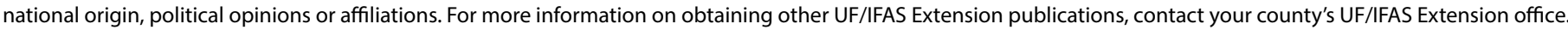
U.S. Department of Agriculture, UF/IFAS Extension Service, University of Florida, IFAS, Florida A \& M University Cooperative Extension Program, and Boards of County Commissioners Cooperating. Nick T. Place, dean for UF/IFAS Extension. 
is practical, cost-effective, and safe for the environment as well as human health. Exclusion, trapping, and sanitation are measures that may not be effective when solely relied upon. The use of avicides may be a supplemental measure to effectively control pest birds.

\section{Avicides Registered for Use in Florida}

\section{What avicides are used for controlling pest birds?}

According to the US Environmental Protection Agency, a "pesticide" is defined (with certain minor exceptions) as:

- any substance or mixture of substances intended for preventing, destroying, repelling, or mitigating any pest

- any substance or mixture of substances intended for use as a plant regulator, defoliant, or desiccant

- any nitrogen stabilizer

There are several classes of avicides, including bait, repellents, and one reproductive inhibitor. Several other classes have been used but are no longer registered for use or are unavailable, including a couple of organophosphate and chlorinated hydrocarbon insecticides, a sterilant, a toxic bait, and a stressing agent. At the time of writing this publication, there are only five active ingredients registered in Florida for control of nuisance birds. The following section will briefly discuss those avicides that are currently registered for use in Florida.

\section{Bait}

4-aminopyridine is a restricted use pesticide due to its acute oral and dermal toxicity and toxicity to birds and mammals. Restricted use pesticides are for retail sale to and use by only certified applicators or persons under their direct supervision and only for those purposes covered by the applicator's certification. This bait is a poison with flock-alarming properties used for the control of feral pigeons. It works in the area of structures that have become feeding, nesting, loafing, and roosting sites. Birds that react and alarm a flock usually die, and some of the flock may react and frighten the rest away. Only a small number of birds need to be affected to alarm the rest of the flock. After one alarming exposure, birds usually will not return to the treated areas.

Products: Avitrol

\section{Repellents}

Polybutene is a transparent, sticky substance used to discourage starlings from roosting or perching on surfaces. For indoor use, it is placed on supports of buildings and structures. For outdoor use, it may be applied adjacent to buildings and structures on trees, bushes, and vines if they are not in bloom or bearing fruit.

Products: Bird B Gone, Bird-X, Hot Foot, 4 The Birds

Methyl anthranilate is used in products to repel birds from turfgrass sites and a wide array of agricultural commodities, as well as to keep birds out of and off of structures and away from feedstuffs and non-fish-bearing bodies of water. The application of methyl anthranilate makes the food supply in the application area very undesirable to birds by irritating their olfactory nerves. Further elimination of the food source will change the feeding habits of these birds and cause them to look for a more desirable feeding location.

Products: Rejex-it, Avian Control, Corvus, Goose Repellent, EcoBird

\section{Reproductive Inhibitor}

Nicarbazin is available as a ready-to-use bait designed for administration to feral pigeons and other pest birds. For efficacy, it must be fed daily during the nesting period and consistently consumed by target birds. Although affected birds continue to lay eggs, the hatch rate is reduced.

Products: OvoControl P

\section{Additional Information}

National Pesticide Information Center (1-800-858-7378 or http://npic.orst.edu/).

Nesheim, O. N., F. M. Fishel, and M. A. Mossler. 2005. Toxicity of Pesticides. PI-13. Gainesville: University of Florida Institute of Food and Agricultural Sciences. http:// edis.ifas.ufl.edu/PI008 